\title{
Current Methods for Seafood Authenticity Testing in Europe: is there a Need for Harmonisation?
}

\author{
Andrew M. Griffiths ${ }^{a, *}$, Carmen G. Sotelo ${ }^{b}$, Rogério Mendes ${ }^{c}$, Ricardo I. Perez Martin ${ }^{b}$, Ute Schröder ${ }^{d}$, \\ Marc Shorten $^{\mathrm{e}}$, Helena A. Silva ${ }^{\mathrm{c}}$, Véronique Verrez-Bagnis ${ }^{\dagger}$, Stefano Mariani $^{\mathrm{a}}$
}

\footnotetext{
a School of Environment and Life Sciences, University of Salford, Greater Manchester, UK

b Instituto de Investigaciones Marinas, Consejo Superior de Investigaciones Científicas, Vigo, Spain

c Portuguese Institute for the Sea and Atmosphere (IPMA) Department for the Sea and Marine Resources, Av. Brasília, 1449-006 Lisbon, Portugal

d Max Rubner-Institute, Department of Safety and Quality of Milk and Fish Products, Germany

e Indigo Rock Marine Research Station, Gearhies, Bantry, Co. Cork, Ireland

${ }^{f}$ Ifremer, rue de l'lle d'Yeu, B.P. 21105, F-44311 Nantes 03, France
}

\author{
*: Corresponding author : Andrew M. Griffiths, tel.: +4407812051365 ; email address : andiff100@googlemail.com \\ carmen@iim.csic.es ; rogerio@ipma.pt ; ricardo@iim.csic.es ; ute.schroeder@mri.bund.de ; \\ marc.shorten@dommrc.com ; hsilva@ipma.pt ; Veronique.Verrez@ifremer.fr ; s.mariani@salford.ac.uk
}

\begin{abstract}
:
Mislabelling of food products has recently received a great deal of public scrutiny, but it remains unclear exactly what methods are being utilised in laboratories testing the authenticity of foods. In order to gain insight into the specific area of the analysis of seafood, a questionnaire focusing on the taxonomic groups typically analysed and the techniques utilised was sent to over one hundred accredited laboratories across the UK, Ireland, Spain, Portugal, France and Germany. Forty-five responded positively, demonstrating significant differences in both the species analysed and methods utilised among the countries included in the survey. Indeed, a diversity of methods was employed across laboratories and efforts to harmonise and/or standardise testing were evident only at national scale. This contrasts with the EU wide scale of regulation on seafood labelling, and may lead to inconsistencies in the results produced in countries.
\end{abstract}

\section{Highlights}

The first international survey of accredited food authenticity laboratories. Significant differences in the methods used in authenticating seafood. Significant differences in the main products monitored. Lack of harmonisation and standardisation across the EU (despite common regulation). - Widespread uptake of DNA-based methods, particularly sequencing.

Keywords : Food testing ; Forensically informative nucleotide sequencing ; Species identification ; DNA barcoding ; Fisheries 


\section{1. Introduction}

59 Mislabelling of food products, so that the description or labelling does not accurately reflect the 60 purveyed food, has recently received a large amount of public attention. This came to great 61 prominence during the 2013 "horse meat scandal" in Europe, where a range of supposedly beef 62 products were found to contain horse flesh (FSAI, 2013). What makes this discovery surprising is that

63 it took place despite the clear set of European Union (EU) regulations relating to food traceability 64 and labelling, which require a complex system of documentation and audit to ensure that food 65 remains authentic and traceable (Schröder, 2008). In fact, it was only through the use of DNA based 66 methodologies for identifying species that this food fraud was detected.

67

68 This case clearly demonstrates the utility of DNA based authenticity techniques as a tool in food

69 control, which have been shown to be particularly useful in the specific case of testing seafood, 70 particularly fish, due to astounding biological diversity that underpins this complex market. The 71 global trade of seafood products over the last 40 years increased from 0.8 million metric tons worth $72 \$ 1.3$ billion in 1975 to 2.4 million metric tons worth $\$ 16.5$ billion in 2012 (NOAA, 2013). This has also 73 been accompanied by greater complexity in commodity flows, with some products crossing multiple 74 national boundaries during the supply chain, including movements into territories without stringent 75 traceability requirements ( $D^{\prime}$ Amico et al, 2014). There is also a huge diversity of species and 76 products available on the global seafood market, such that the U.S. Food and Drug administration 77 includes approximately 1700 species of commercial finfish and shellfish in its Seafood list (FDA, 78 2013).

80 Whilst species identification can usually be made from morphological characteristics from fish in

81 their whole form, seafood is often processed before reaching the consumer. This potentially creates 
82 a situation where substitution of species, particularly for economic gain (i.e. where a low value

83 product is substituted for a higher value one) may occur, but is difficult/impossible to identify

84 without authenticity testing. Indeed, numerous genetic studies have now been published that

85 demonstrate high levels of substitution and mislabelling across a variety of seafood products (e.g.

86 Griffiths et al. 2013; Rehbein \& Oliveira, 2012; Miller \& Mariani, 2010; Wong \& Hanner, 2008).

88 These studies have clearly demonstrated that seafood mislabelling is a widespread phenomenon,

89 but they also highlight the huge diversity of methodologies that have been developed for

90 identifying/distinguishing between species. The exhaustive recent reviews by Rasmussen \&

91 Morrissey (2008), Teletchea (2009) and Lago et al. (2013) emphasise the fact that many traditional

92 and official methods used in species identification are based on the biochemical analysis of specific

93 proteins, e.g. isoelectric focusing (IEF), high performance chromatography or immunoassay. These

94 approaches have a number of disadvantages, the most significant being that many can only be

95 applied to fresh samples, and they cannot be used on highly processed (i.e. cooked or canned

96 products) because the proteins become denatured upon heating. In comparison, DNA is a more

97 thermostable molecule and although it may become degraded during processing, short fragments

98 are generally recoverable and can form the basis of authenticity tests in processed foods (Quinteiro

99 et al., 1998; Mackie et al., 1999). Furthermore, detailed surveys of the scientific literature on

100 seafood authenticity reveal it to be a continuously evolving field, with over 150 peer-reviewed

101 papers on the topic in the period 1995-2008 (Rasmussen \& Morrissey, 2009; Teletchea, 2009).

103 Against this backdrop of increasing regulatory complexity and technological development, it is 104 unclear what methods are actually being utilised in public and private authenticity laboratories. The 105 EU regulations concerning food labelling and traceability contain little/no guidance on what 
106 techniques should be applied and no recognition of an "official" method. While the plethora of DNA

107 techniques available offers undeniable advantages in biological identification, their ability to

108 distinguish particular groups of species may vary considerably. Therefore, the aim of this study was

109 to survey public and private laboratories that conduct seafood authenticity testing across Europe to

110 investigate how products, particularly finfish products, are analysed. This knowledge is vital in a

111 regulatory and legal context as it remains key to accurately testing food and providing robust

112 evidence for prosecuting those that break the law. It also represents a fundamental step towards the

113 establishment of an efficient, validated, standardised transnational procedure for monitoring

114 authenticity in the seafood market.

\section{2. Materials \& Methods}

\subsection{Survey Development}

118 In order to maximise the number of responses, a relatively simple questionnaire was constructed,

119 which included eight brief questions and avoided asking for commercially sensitive information that

120 could potentially have prevented response from commercial or private laboratories (supplementary

121 material 1). The key questions posed were;

-Are you a public or private testing facility?

124 -What species are you most commonly asked to check for mislabelling?

125 -What biochemical or molecular method(s) do you use for distinguishing between species in the 126 analysis of sea-foods? 
127 In any molecular genetic methods, what region of the DNA do you use (nuclear vs mitochondrial,

128 specific protein coding genes or non-coding regions; can you tell us which you use for each

129 taxonomic group)?

130 -Are you developing any novel approaches that you could tell us about in broad terms?

132 The remaining questions were related to the methodologies employed and generally concerned the

133 capabilities of the laboratories i.e. in terms of equipment, specificity of methods and the extent of

134 reference data collected.

135

136 The questionnaire was translated and e-mailed to 101 authenticity laboratories involved in the

137 testing of seafood in the United Kingdom (UK), Republic of Ireland (ROI), France, Germany, Spain and

138 Portugal, which include five of the top ten countries in Europe in terms of total supply of fisheries

139 products (FAO, 2009). The questionnaires were initially sent out in November 2012, with efforts to

140 elicit responses continuing until March 2013. How laboratories were short-listed in each country

141 varied, but efforts were made to contact both public and private authenticity facilities that have

142 some degree of officially recognised accreditation (e.g. from the United Kingdom Accreditation

143 Service, Portuguese Institute for Accreditation, National Association of German Chemists, Spanish

144 National Entity for Accreditation or French Committee of Accreditation). However, given the survey's

145 authors' experience in the field, questionnaires were also distributed through previously established

146 networks of contacts. 
149 Given that the amount of detail provided by different laboratories to many questions varied

150 considerably, efforts were made to standardise answers by grouping specific responses into broader

151 categories, prior to statistical analyses. Additionally, as single responses were gathered from

152 Portugal and ROI, these were combined with those from their geographically and culturally most

153 proximate neighbours; Spain and UK, respectively, for statistical testing.

154

155 To explore general patterns in the data, principal component analysis (PCA) was conducted in 156 PRIMER-6 (Clarke \& Warwick, 2001), with each testing laboratory representing an individual data

157 point in the ordination. The software was also used to conduct a non-parametric analysis of 158 similarity (ANOSIM), utilising the Bray-Curtis distance measure. Specifically, the ANOSIM was used to 159 test if there were significant differences between countries in terms of the types of products/species 160 laboratories commonly test, and also for differences in the authenticity methods employed. The 161 hypothesis being that different countries will have cultural differences in the seafood products they 162 consume, leading to significant differences in the types of products analysed and the authenticity 163 methodologies tailored to them.

\section{3. Results}

166 Of the 101 laboratories contacted, 45 responded positively; a response rate of $44.6 \%$. Across all the 167 countries included, a total of 30 completed questionnaires were gathered from public laboratories 168 and 15 from private facilities (summarised in supplementary material 2). The results for the 169 responses to the key questions are examined below, one at a time.

171 What species are you most commonly asked to check for mislabelling? 
172 A total of 38 laboratories provided information on the species they typically test and the level of

173 detail provided varied considerably, some facilities listed Latin names, whilst others included much

174 broader commercial designations. Therefore, the responses were classified into wider taxonomic

175 groups, which also included species that are commonly used as substitutes e.g. the gadoid

176 classification includes any responses of: "cod", "haddock", "gadoids", "white fish" and "pangasius"

177 or "panga", as species from the tropical catfish Pangasiidae have widely been used as a substitute

178 for gadoids. A total of 18 classes were constructed (of which nine included only one or two records,

179 see supplementary material 3). By far the most commonly tested species groups were: gadoids, flat

180 fish, tunas and salmonids. Global comparisons were highly significant $(R=0.447, p$-value $=0.001$,

181 table 1), suggesting big differences between the countries in terms of the products and species

182 commonly tested. A simplified version of the dataset, with the species classes that only

183 incorporating one or two records removed, was analysed via PCA in order to reduce the number of

184 variable vectors and make the figure clearer (fig. 1, the PCA with all vectors is also included in

185 supplementary materials 4). It clearly demonstrates how testing in the UK, ROI and France is

186 dominated by gadoids and salmonids, whilst flat fish are more predominant in Germany and a

187 combination of hakes, clupeids and tunas are important in Spain and Portugal.

189 What biochemical or molecular method(s) do you use for distinguishing between species in the 190 analysis of seafood?

191 All 45 laboratories answered this question. Similar to above, the responses were grouped into 12 broader methodological classes (supplementary material 5). So for example, any sequencing based identification methods, regardless of the gene/region targeted were classed under forensically

194 informative nucleotide sequencing (FINS). The three most widely utilised methods were FINS (in 31

195 laboratories), restriction fragment length polymorphism (RFLP, in 18) and IEF (in nine). This reflects

196 the fact the DNA-based methods were far more prevalent, with only 10 of the laboratories including 
197 a biochemical protein-based protocol in their response. Global testing of the results demonstrated

198 significant differences between countries (ANOSIM; $R=0.259 p=0.001$, table 1). Further comparison

199 of the pairwise tests between countries shows that much of this result is due to the UK \& ROI group

200 (for which all three tests against other groups were significant at the 95\% confidence interval, table

201 1). A simplified version of the dataset, where classes of method with a single record were removed

202 in order to reduce the number of variable vectors, was analysed via PCA (fig. 2, the PCA with all

203 vectors is also included in supplementary materials 6). It shows the importance of FINS, RFLP and IEF

204 across Europe, but there is little evidence of different patterns in methodological application

205 between countries surveyed.

207 The survey included three further questions that are related to methods of choice. First, "are your 208 methods universal or tailored to specific groups of fish?" Thirty nine laboratories responded, two 209 said their methods were specific to certain groups, 17 utilised universal methods and 20 used both.

210 Second, "have you developed your own databases of reference material or baseline information to 211 distinguish between species?" All 45 laboratories responded, 11 exclusively employed public 212 databases, 16 utilised their own private reference data and 18 used both. Finally, "what key pieces

213 of equipment do you use in distinguishing between species?" The majority of laboratories that 214 responded to this question indicated they had access to basic molecular biology equipment e.g. PCR 215 machines, electrophoresis kit etc.

217 In any molecular genetic methods, what region of the DNA do you use (nuclear vs mitochondrial, 218 specific protein coding genes or non-coding regions; can you tell us which you use for each taxonomic 219 group)? 
22040 laboratories gave some indication of the DNA they target across the methodologies they utilise.

221 Only 10 of these specified that at least some of their methods utilised nuclear DNA, and these

222 involved a wide range of targets, both anonymous DNA regions e.g. microsatellites and randomly

223 amplified polymorphic DNA (RAPD) and specific genes e.g. rhodopsin and pantophysin

224 (supplementary material 7). Conversely, all 40 laboratories positively indicated mitochondrial DNA

225 was a focus of their authenticity testing. Three gene regions proved to be the markers of choice;

226 Cytochrome B (cyt-b, specified in 29 responses), cytochrome oxidase 1 (COI, in 11) and 16s

227 ribosomal DNA (16s, in 7). Global testing of the results failed to detect significant differences

228 between countries, although the result was very close to the $95 \%$ confidence interval (ANOSIM; $R=$

$2290.121 \mathrm{p}=0.050$, table 1$)$.

230

231 Are you developing any novel approaches that you could tell us about in broad terms?

232 Only two laboratories declined to answer this question, but the remaining 43 responses were 233 generally in the negative. Interestingly, of the nine laboratories who indicated the technologies they 234 were currently investigating, six specified "real time" PCR (rtPCR) based methods.

237 This work represents the first effort to assess what methodologies are being applied to seafood

238 authenticity in Europe. There are some very clear patterns that emerge from the responses: firstly,

239 the groups of species tested across the regions varied significantly. Second, DNA based methods,

240 particularly FINS, dominated the responses, but approaches were inconsistent between laboratories,

241 and protein based biochemical methods are still commonly utilised. Although a total sample size of

24245 laboratories does not necessarily provide enough data to investigate subtler dynamics within and

243 between countries, some patterns are very strong and reveal a substantial lack of standardisation. 
245 This survey identified highly significant differences in the species commonly tested in the countries

246 surveyed, which is entirely consistent with the cultural preferences for seafood across these regions.

247 A range of white fish species are commonly consumed in northern France, UK and ROI, which is 248 clearly reflected in figure 1. Similarly, a culture of consuming hake and clupeids in Spain and Portugal 249 and the high value attached to sole (Solea solea) in Germany, are also reflected in the results. It 250 seems very likely that if further regions of Europe were surveyed-with their own traditions of 251 consuming seafood - even more complex patterns in the species tested would emerge (Armani et 252 al., 2012a). This presents a significant issue in terms of harmonising and standardising approaches to 253 seafood authenticity across Europe, to which the EU is generally committed, and for which all 254 member states are governed by the same regulations regarding traceability and authenticity. It is 255 due to the fact that laboratories in various countries are likely to be more familiar with testing for a 256 discrete sub-set of species (and may have developed methods optimised to these groups), but any 257 standard methodology will have to function across a much broader taxonomic range that reflects 258 the diversity of cultural preferences in seafood consumption across the EU, and the progressively 259 more globalised import landscape of the EU (Sotelo \& Pérez-Martín, 2007; De Silva, 2010; Armani et 260 al., 2012b). Nevertheless, it is important to note that there are existing efforts to harmonise testing 261 of seafood, for example, the Food Analysis Performance Assessment Scheme (FEPAS; 262 http://fapas.com) provides a regular fish authenticity proficiency testing scheme. This involves the 263 analysis of "blind" samples, i.e. where the species of origin is unknown, which can be incorporated 264 into the requirements of national accreditation bodies. In Germany, harmonisation has gone a step 265 further; under the German Food and Feed Act ( $\$ 64$ Lebensmittel- und Futtermittelgesetzbuch), ring 266 trials have been used to develop a range of officially recognised standard methods, which are 267 coordinated by the Federal Office of Consumer Protection and Food Safety (BVL; 268 http://www.bvl.bund.de). However, this also emphasises how harmonisation has largely been driven 269 at a national, but not EU-wide, scale. 
271 Despite the view that traditional and official methods used in species identification are based on the

272 analysis of specific proteins (Rasmussen \& Morrissey, 2008; Teletchea, 2009), the majority of

273 authenticity laboratories routinely employ DNA based protocols in their analysis of seafood and have

274 access to equipment for basic molecular genetics. This can been seen as further evidence that

275 control laboratories, which are traditionally seen as being staffed by analytical chemists, are

276 embracing genetic tools for distinguishing species (Wolfe et al., 2013). Nevertheless, it is important

277 to note that IEF is still commonly utilised, remaining the third most commonly employed class of

278 method. This probably relates to the low-cost and speed of the protocol (making it an ideal approach

279 for an initial screening of samples), and the long period it has been the Association of Analytical

280 Communities (AOAC) recognised method for species identification (AOAC, 1980).

282 The widespread use of DNA based methods does not necessarily mean that the protocols across the

283 laboratories are standardised. The surveyed laboratories utilised a diverse set of techniques and a

284 global test across all regions was significant, suggesting differences in the methods applied between

285 countries. In particular, the UK and ROI group was generally identified as using a distinct set of

286 methods to those in the rest of Europe. This reflects previous efforts of the Food Standards Agency's

287 Food Authenticity Programme to transfer DNA methodologies to UK Official Food Control

288 laboratories. They supported knowledge transfer activities and provided funding for a standard 289 operating procedure (SOP) based on a RFLP protocol on a lab-on-a-chip platform (Agilent 2100

290 Bioanalyser) for species identification (Dooley et al., 2010; Garrett et al., 2010). So the majority of

291 public analyst laboratories follow the same SOP, probably making this one of the largest efforts to

292 standardise seafood authenticity testing with a single method in Europe. However, the use of a RFLP

293 technique in the UK contrasts with the more widespread application of FINS in the rest of Europe. 
294 The PCA scatter also illustrates how the variation in techniques used is considerable, even within 295 most countries.

296 The grouping of protocols into broader methodological classes to facilitate the statistical analysis

297 actually disguises the full diversity of approaches revealed by the questionnaires. So for example, 298 FINS was the most commonly utilised class of method, but it includes many laboratories with 299 different target sequences, and even where laboratories utilise the same genetic region it does not 300 necessarily imply the same primers/protocol are being applied (Burgener \& Hübner, 1998; Sevilla et 301 al., 2007). The subsequent question in the survey, regarding the regions of DNA targeted, helps clarify this issue to some degree. It demonstrates a relatively wide diversity of DNA targets, both nuclear and mitochondrial, with mitochondrial regions dominating. This reflects several advantages mitochondrial DNA presents in authenticity testing, particularly its haploid matrilineal inheritance and its high copy number within the cell (Rasmussen \& Morrissey, 2008; Teletchea, 2009). It is also interesting to note that despite the global Barcode of Life initiative promoting the sequencing of $\mathrm{COI}$ for identifying species (Ratnasingham \& Hebert, 2007) and the US Food and Drug Administration developing this as a validated method utilised for seafood authenticity, cyt-b remains the most popular DNA target (although, since these responses refer to any DNA based method, not just FINS,

310 there may be a systematic inflation of the role of cyt-b, as this region has been long optimised for 311 RFLP analysis).

313 This survey revealed the diversity of biochemical and genetic methods that are used in laboratories 314 across Europe, demonstrating a general lack of standardisation in testing between laboratories. This 315 has important implications, essentially meaning that if the same sample was analysed in different 316 laboratories, conflicting results could be generated or, more likely, the majority of specific tests for a 317 narrow range of species/products will simply fail to identify the sample. However, inconsistency may 318 also arise when considering the reference data that is being utilised to perform species 
319 identification. The survey specifically included a question concerning whether the laboratories

320 employed their own private, or a publically available, database (with some using only private or

321 public databases, and others a combination). Both kinds of databases could potentially be associated

322 with inconsistent identifications. Public databases tend to be the most comprehensive, but may

323 contain sequences erroneously attributed to the wrong species, which may require some

324 interpretation. Conversely, private data collections may differ significantly between laboratories,

325 producing an additional source of inconsistencies when comparing results. The use of reference

326 tissues is an aspect that will play a part in future improvements of method standardization. While

327 sequencing-based approaches rely on large amount of reference data stored in public data bases

328 (e.g. GenBank, http://www.ncbi.nlm.nih.gov/; BOLD, www.boldsystems.org) most other techniques

329 hinge on the existence of voucher specimens in the control labs, whose provision and exchange

330 would represent a challenge for a robust, wide-spectrum, long-lasting standardisation initiative.

331 Even the choice of sequence data bases in support of FINS should be based on the level of

332 maintenance, verification and filtering of the said sequences, in order to minimize the risk of "false

333 matches", especially for less commonly traded species. Failure to consider these constraints will

334 have serious implications within the context of enforcement and prosecution, acting to undermine

335 the confidence of stakeholders.

\section{5. Conclusions}

Despite the view that most traditional methods used in species identification are based on the

339 biochemical analysis of specific proteins, DNA sequencing appears to be the most commonly applied

340 approach (with the analysis of the cytochrome-b gene dominating). However, there is a diversity of

341 approaches that highlights the lack of consistency in how protocols for identifying species in seafood

342 are applied at a European level. This absence of harmonisation and standardisation could lead to

343 inconsistencies in results generated between laboratories, which may have significant regulatory or 
344 legal implications. These results underline the need for a more rigorous standard operating

345 procedure to be applied across the EU. Previous attempts to develop standard approaches to

346 seafood identification at a national scale have been successful, both within the UK (Wolfe et al.,

347 2013) and the US (Handy et al., 2011), demonstrating the feasibility of such an approach.

\section{Acknowledgements}

350 We thank all those authenticity laboratories and staff who took the time to complete the

351 questionnaire. This work was funded by the European Union INTERREG Atlantic Area Program 352 ('LabelFish', project 2011-1/163). Additional support also originated from The Department for 353 Environment, Food and Rural Affairs (DEFRA), in the United Kingdom.

355 References

356 AOAC. (1980). Official Method 980.16 Identification of Fish Species: Thin-Layer Polyacrylamide Gel 357 Isoelectric Focusing Method. Journal of AOAC International, 63:69.

359 Armani, A., Castigliego, L., Tinacci, L., Gandini, G., Gianfaldoni, D., \& Guidi, A. (2012a). A rapid PCR360 RFLP method for the identification of Lophius species. European Food Research and Technology, 235, $361 \quad 253-263$.

363 Armani, A., Castigliego, L., \& Guidi, A. (2012b). Fish fraud: The DNA challenge. CAB Reviews 20127 , 364 No 071. 
366 Burgener, M., \& Hübner, P. (1998). Mitochondrial DNA enrichment for species identification and evolutionary analysis. Zeitschrift für Lebensmitteluntersuchung und-Forschung A, 207, 261-263.

369 Clarke K. R., \& Warwick R. M. (2001). Change in marine communities: an approach to statistical 370 analysis and interpretation, 2nd edn. Plymouth Marine Laboratory, Plymouth, UK.

372 D’Amico P., Armani A., Castigliego L., Sheng G., Gianfaldoni D., \& Guidi. A. (2014). Seafood 373 traceability issues in Chinese food business activities in the light of the European provisions. Food 374 Contol, 35, 7-13.

376 De Silva, D. A. M. (2010). Value chain of fish and fishery products: origin, functions and application in 377 developed and developing country markets, Value chain project, Food and Agriculture Organisation 378 (FAO), Rome Italy. pp 7-10.

Dooley, J., Garrett, S., Sage, H., Clark, M., \& Brown, H. (2010). Application of a chip-based capillary electrophoresis system to enable simple PCR detection of fish species. Project Code: Q01069. Food http://www.foodbase.org.uk/results.php?f_report_id $1 / 495$ (accessed 03.11.12) 
388 FDA (Food and Drug Administration). (2013). The Seafood List FDA's guide to acceptable market

389 names for seafood sold in interstate commerce,

390 http://www.fda.gov/food/guidanceregulation/guidancedocumentsregulatoryinformation/seafood/u

$391 \mathrm{cm113260.htm} \mathrm{(accessed} \mathrm{December} \mathrm{16,} \mathrm{2013).}$

392

393 FSAI (Food Safety Authority of Ireland). (2013). Horse meat used to cheat consumers. FSAI News 394 January/February 2013, Vol. 15, Issue 1. FSAI, Dublin.

395

396 Garrett, S., Dooley, J., Brown, H., \& Clarke, M. (2010). Extending the fish species lab-on-a-chip

397 capillary electrophoresis PCR-RFLP database. Food Standards Agency, Foodbase, Open Access

398 Research RepositoryProject Code: Q01099, Available at;

399 http://www.foodbase.org.uk/results.php?f_report_id $1 / 4532$. (Accessed 03.11.12)

400

401 Griffiths, A. M., Miller, D. D., Egan, A., Fox, J., Greenfield, A., \& Mariani, S. (2013). DNA barcoding 402 unveils skate (Chondrichthyes: Rajidae) species diversity in 'ray'products sold across Ireland and the 403 UK. PeerJ, 1, e129.

404

405 Handy, S. M., Deeds, J. R., Ivanova, N. V., Hebert, P. D., Hanner, R., Ormos, A., Weigt, L. A., Moore, 406 M. M., Hellberg, R. S., \& Yancy, H. F. (2011). Single laboratory validated method for DNA-barcoding 407 for the species identification of fish for FDA regulatory compliance. Journal of AOAC International, $40894,201-210$. 
410 Hellberg, R. S. R., \& Morrissey, M. T. (2011). Advances in DNA-based techniques for the detection of

411 seafood species substitution on the commercial market. Journal of the Association for Laboratory

412 Automation, 16, 308-321.

413

414 Lago, F. C., Alonso, M., Vietes, J. M., \& Espineira, M. (2013). Fish and Seafood Authenticity - Species

415 Identification, In I. S., Bozaris (ed.), Seafood Processing Technology, Quality and Safety, (pp. 419-

416 440). John Wiley \& Sons, Ltd, Chichester, UK.

418 Mackie I.M., Pryde S., González-Sotelo C., Medina I., Pérez-Martín R.I., Quinteiro J., Rey-Mendez M., 419 Rehbein H. (1999). Challenges in the identification of species of canned fish. Trends in Food Science 420 and Technology, 10: 9-14.

Miller, D. D., \& Mariani, S. (2010). Smoke, mirrors, and mislabeled cod: poor transparency in the

European seafood industry. Frontiers in Ecology and the Environment, 8, 517-521

NOAA (National Oceanic and Atmospheric Administration). (2013). Imports and exports of fishery products annual summary, http://www.st.nmfs.noaa.gov/st1/publications.html (accessed December

427 16, 2013).

429 Quinteiro J., Sotelo C. G., Rehbein H., Pryde S. E., Medina I., Pérez-Martín R. I., Rey-Méndez M., \&

430 Mackie I. M. (1998). The use of mtDNA direct PCR-sequencing and PCR-RFLP methodologies in 431 species identification of canned tuna. Journal of Agricultural and Food Chemistry, 46, 1662-1669. 
433 Rasmussen, R. S., \& Morrissey, M. T. (2008). DNA-Based Methods for the Identification of 434 Commercial Fish and Seafood Species. Comprehensive reviews in food science and food safety, 7, $435 \quad 280-295$.

436

437 Rasmussen, R. S., \& Morrissey, M. T. (2009). Application of DNA-Based Methods to Identify Fish and 438 Seafood Substitution on the Commercial Market. Comprehensive Reviews in Food Science and Food 439 Safety, 8, 118-154.

440

441 Ratnasingham S., \& Hebert P. D. N. (2007). BOLD: the barcode of life data system. Molecular Ecology 442 Notes, 7, 355-364.

443

444 Rehbein, H., \& Oliveira, A. C. (2012). Alaskan flatfishes on the German market: part 1: identification 445 by DNA and protein analytical methods. European Food Research and Technology, 234, 245-251.

447 Sevilla, R. G., Diez, A., Norén, M., Mouchel, O., Jerome, M., Verrez-Bagnis, V., Van Pelt, H., Favre448 Krey, L., Krey, G., The Fishtrace Consortium \& Bautista, J. M. (2007). Primers and polymerase chain 449 reaction conditions for DNA barcoding teleost fish based on the mitochondrial cytochrome $b$ and 450 nuclear rhodopsin genes. Molecular Ecology Notes, 7, 730-734.

452 Schröder, U. (2008). Challenges in the traceability of seafood. Journal of Consumer Protection and 453 Food Safety, 3, 25-28. 
454

455 Sotelo C. G., \& Pérez-Martín R. I., (2007). Fish and Seafood Authentication. In S. E. Ebeler, G. R. 456 Takaoka, \& P. Winterhalter (Eds.), Authentication of Food and Wine (pp.126-137). ACS Symposium 457 Series.

458

459 Teletchea, F. (2009). Molecular identification methods of fish species: reassessment and possible 460 applications. Reviews in Fish Biology and Fisheries, 19, 265-293.

461

462 Woolfe, M., Gurung, T., \& Walker, M. J. (2013). Can Analytical Chemists do Molecular Biology? A 463 Survey of the Up-skilling of the UK Official Food Control System in DNA Food Authenticity 464 Techniques. Food Control, 33, 385-392.

465

466 Wong, E. H. K., \& Hanner, R. H. (2008). DNA barcoding detects market substitution in North 467 American seafood. Food Research International, 41, 828-837. 
469 Figure 1. PCA the species commonly tested in each authenticity laboratory. PC 1 incorporates $25.3 \%$

470 and PC $218.9 \%$ of the variation (eigenvalues $=0.382$ and 0.286 , respectively).

471

472 Figure 2. PCA the methods utilised in each authenticity laboratory. PC 1 incorporates $42.5 \%$ and PC 2

$47327.4 \%$ of the variation (eigenvalues $=0.339$ and 0.218 , respectively). Methodological abbreviations;

474 FINS = forensically informative nucleotide sequencing, RFLP = restriction fragment length

475 polymorphism, IEF isoelectric focusing, rtPCR = real-time polymerase chain reaction \& SSprimers = 476 species specific primers. 
478 Table 1. Results of the ANOSIM testing for differences in responses among the countries surveyed.

479 Both global and pair-wise tests between countries are included. Results significant at the 95\%

480 confidence interval are highlighted in bold, those remain significant after sequential Bonferroni

481 correction (initial value $0.05 / 7$ ) are also marked with *.

\begin{tabular}{|c|c|c|c|c|c|c|}
\hline \multirow[t]{2}{*}{ Test } & \multicolumn{2}{|l|}{ Species } & \multicolumn{2}{|l|}{ Methods } & \multicolumn{2}{|c|}{ DNA Markers } \\
\hline & R statistic & p-value & R statistic & $p$-value & R statistic & $p$-value \\
\hline Global & 0.447 & $0.001 *$ & 0.259 & $0.001^{*}$ & 0.121 & 0.050 \\
\hline $\begin{array}{l}\text { UK/ROI \& } \\
\text { Spain/Portugal }\end{array}$ & 0.633 & 0.091 & 0.362 & $0.001^{*}$ & 0.320 & $0.002 *$ \\
\hline $\begin{array}{l}\text { UK/ROI \& } \\
\text { France }\end{array}$ & 0.229 & $0.001 *$ & 0.366 & 0.026 & 0.158 & 0.364 \\
\hline $\begin{array}{l}\text { UK/ROI \& } \\
\text { Germany }\end{array}$ & 0.377 & 0.035 & 0.358 & $0.001 *$ & -0.034 & 0.675 \\
\hline $\begin{array}{l}\text { Spain/Portugal } \\
\text { \& France }\end{array}$ & 0.394 & $0.001 *$ & 0.156 & 0.130 & 0.037 & 0.444 \\
\hline $\begin{array}{l}\text { Spain/Portugal } \\
\text { \& Germany }\end{array}$ & 0.526 & $0.001^{*}$ & 0.041 & 0.200 & 0.180 & 0.026 \\
\hline $\begin{array}{l}\text { France \& } \\
\text { Germany }\end{array}$ & 0.276 & 0.062 & 0.383 & $0.011 *$ & -0.005 & 0.505 \\
\hline
\end{tabular}

482

483 


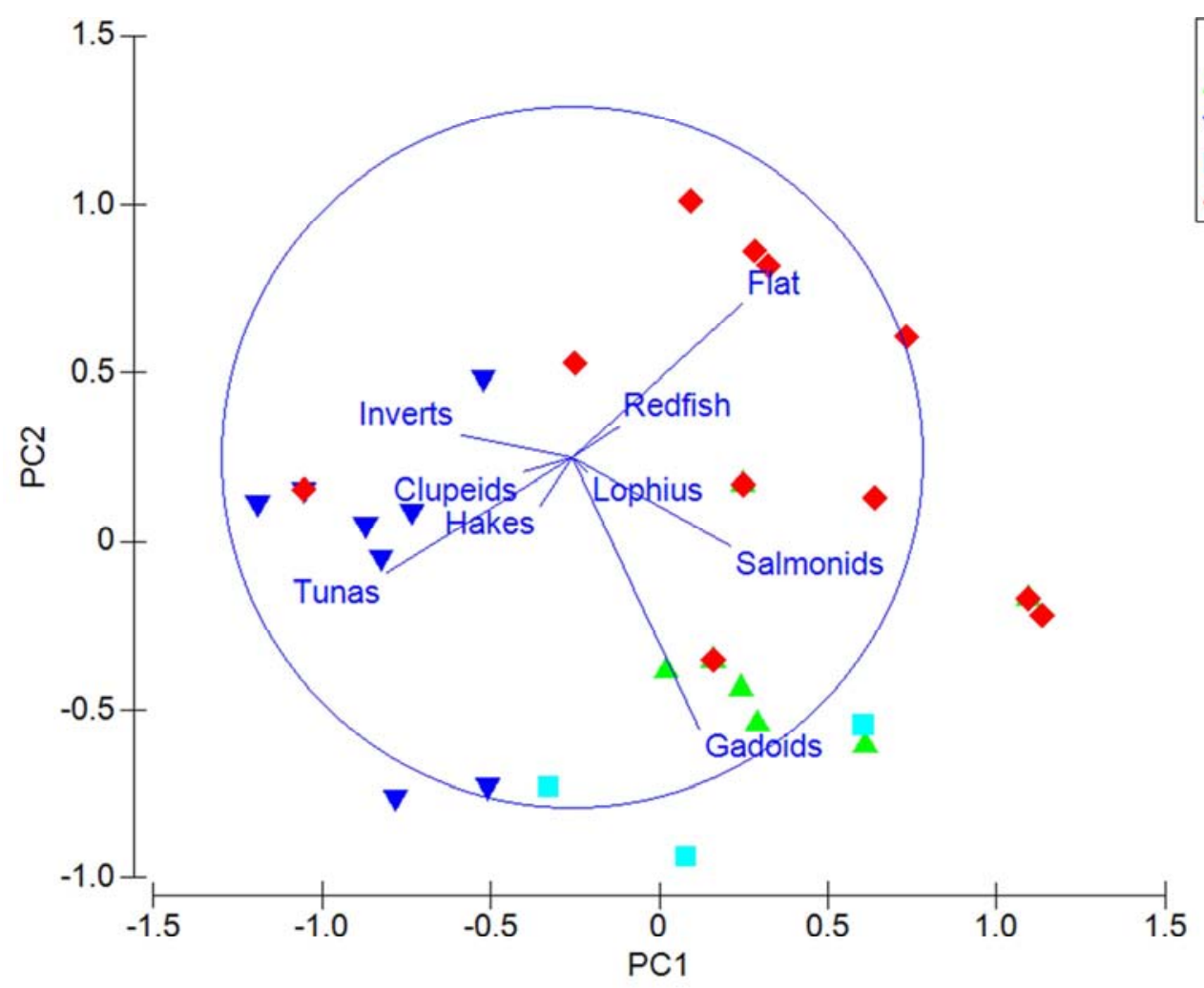

Country

$\triangle$ UK \& ROI

\ Spain \& Portugal

France

Germany 


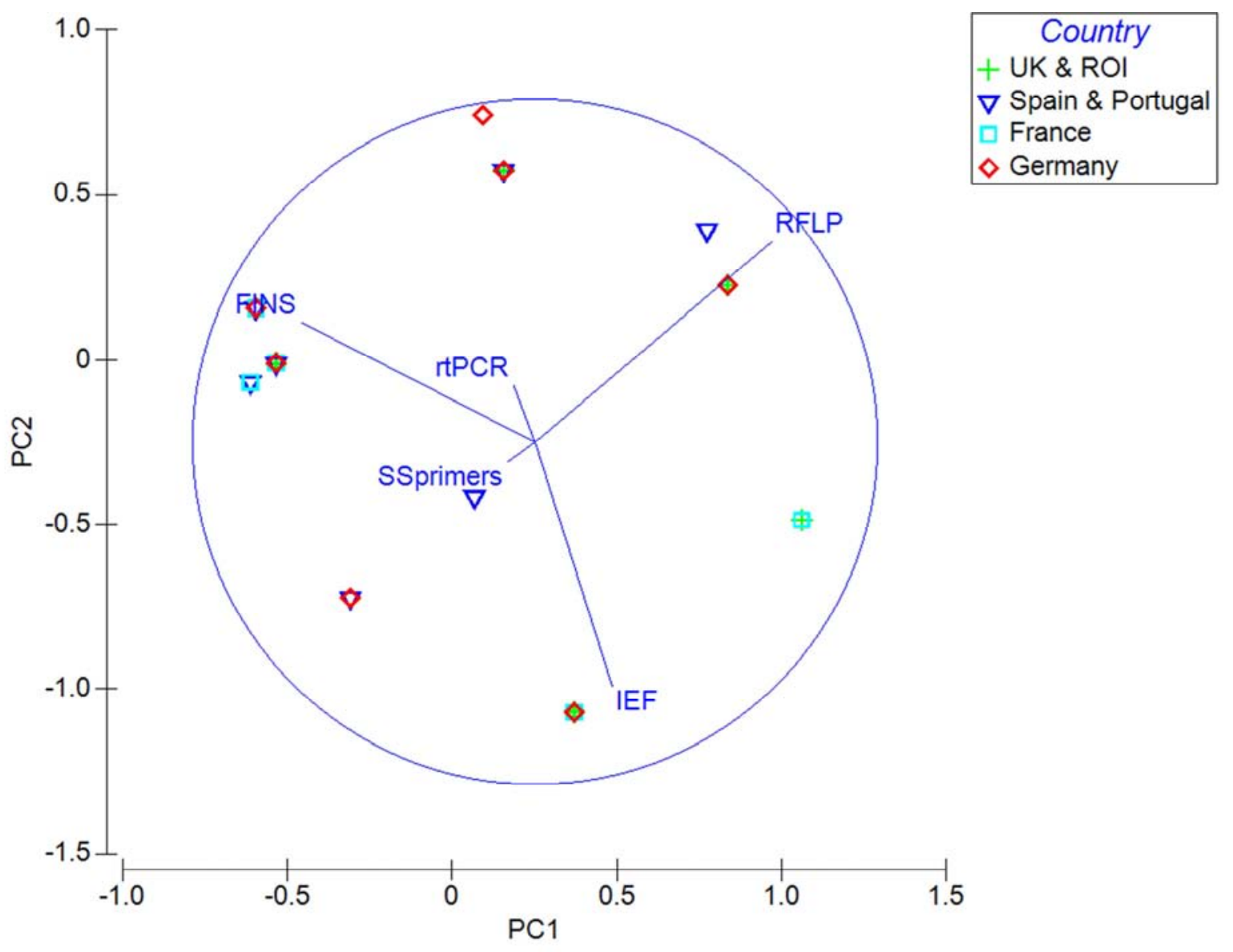


LabelFish is an EU effort to try and understand exactly what methods are currently being used for the identification of species in seafood. Once we have a better understanding, it is hoped that we can then propose more harmonised approaches that will allow investigation of mislabelling and traceability across Europe. Therefore, we ask for a little bit of information (nothing commercially sensitive, so please omit or be less specific on any questions you are unable to answer), to help us realise this objective.

These are our key questions:

- Are you a public or private testing facility?

- What biochemical or molecular method(s) do you use for distinguishing between species in the analysis of sea-foods?

- In any molecular genetic methods, what region of the DNA do you use (nuclear vs mitochondrial, specific protein coding genes or non-coding regions; can you tells us which you use for each taxonomic group)?

- What key pieces of equipment do you use in distinguishing between species?

- Are your methods universal or tailored to specific groups of fish?

- What species are you most commonly asked to check for mislabelling?

- Have you developed your own databases of reference material or baseline information to distinguish between species? How extensive are they?

- Are you developing any novel approaches that you could tell us about in broad terms?

The aim of LabelFish is not to develop new methods of species identification in the analysis of seafood, but find out how best to standardise the most effective approaches currently used across Europe. So, if you can give us any information it could help towards specific methods being employed more widely!

Thanks for any help you can provide! 


\begin{tabular}{|c|c|c|c|}
\hline & ACGIIII & DIVIAIVUSGII & 1 \\
\hline Country & Method & Universal or Specific & DNA region \\
\hline UK & $\begin{array}{l}\text { Isoelectric focusing } \\
\text { (Aglient/RFLP) }\end{array}$ & & \\
\hline UK & FINS, RFLP/Agilent & Universal & Cyt b, cOI \\
\hline UK & RFLP/Agilent & Both & Cyt b, COI \\
\hline UK & RFLP/Agilent & Universal & Cyt b \\
\hline UK & RFLP & Both & Cyt b \\
\hline UK & RFLP/Agilent, FINS & Both & + \\
\hline UK & RFLP/Agilent & Both & 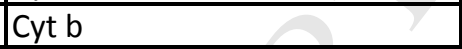 \\
\hline UK & $\begin{array}{l}\text { Isoelectric focusing } \\
\text { (Aglient/RFLP) }\end{array}$ & Both & Cyt b \\
\hline UK & $\begin{array}{l}\text { Electrophoresis Phast system } \\
\text { (Isoelectric focusing) }\end{array}$ & & \\
\hline UK & RFLP/Agilent & Universal & Cyt b \\
\hline Spain & FINS & both & mitochondrial (Cyt b, COI, 16S) \\
\hline Spain & FINS, Real Time-PCR & both & mitochondrial (Cyt b, COI) \\
\hline Spain & FINS,SDS-PAGE, IEF, RAPD & Universal & $\begin{array}{l}\text { Nuclear (RAPD), mitochondrial } \\
\text { (Cyt b) }\end{array}$ \\
\hline Spain & FINS & Specific & Nuclear, mitochondrial \\
\hline Spain & FINS & & mitochondrial (Control region) \\
\hline Spain & FINS, Specific primers & both & $\begin{array}{l}\text { mitochondrial (Cyt b, COI, 16S, } \\
\text { control region) }\end{array}$ \\
\hline Spain & Real Time-PCR, RFLP & universal & mitochondrial \\
\hline Spain & SNPS, FINS, ELISA & universal & mitochondrial (COI, Cyt b) \\
\hline Spain & FINS, RFLP & both & mitochondrial \\
\hline Spain & FINS, RFLP & both & Nuclear and mitochondrial \\
\hline Spain & multiplex PCR, Specific primers & both & Mithochondrial, nuclear (non co \\
\hline France & specific PCR, FINS, DHPLC & both & $\begin{array}{l}\text { mitochondrial (Cyt b) for FINS } \\
\text { and DHPLC - confidential for } \\
\text { specific PCR }\end{array}$ \\
\hline France & $\begin{array}{l}\text { FINS, next generation } \\
\text { sequencing }\end{array}$ & Universal (patented) & mitochondrial \\
\hline France & IEF, RFLP, & & $\begin{array}{l}\text { Nuclear (pantophysin), } \\
\text { mitochondrial (Cyt b) }\end{array}$ \\
\hline France & IEF & & \\
\hline France & PCR, RT-PCR, sequencing, clon & both & all depending on species or grou \\
\hline ROI & $\begin{array}{l}\text { FINS, microsateliite } \\
\text { assignment }\end{array}$ & both & Cyt b, microsatellites \\
\hline \begin{tabular}{|l|} 
Portugal \\
\end{tabular} & FINS & both & 16S rDNA, Cyt b, COI \\
\hline Germany & L 11.00-7, L 11.00-12 & universal & Cytb, \\
\hline Germany & $\begin{array}{l}\text { PCR, Realtime PCR, } \\
\text { RFLP, Sequencing }\end{array}$ & universal /specific & $\begin{array}{l}\text { Cytb, CytOx, } \\
\text { 16SrRNA, Tmo-4C4, myostatin }\end{array}$ \\
\hline Germany & L 11.00-12 & universal & mitochondrial DANN \\
\hline
\end{tabular}




\begin{tabular}{|c|c|c|c|}
\hline Germany & $\begin{array}{l}\text { ACCIT } \\
\text { PCR-Sequencing }\end{array}$ & universal & Cytb, \\
\hline Germany & L 11.00-12 & universal & Cytb, \\
\hline Germany & L 11.00-6 & - & - \\
\hline Germany & L 11.00-12 & universal & 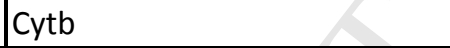 \\
\hline Germany & L 11.00-12 & $\begin{array}{l}\text { generelly universal, } \\
\text { sometimes specific }\end{array}$ & $\begin{array}{l}\text { Cytb ( §64-Method) } \\
\text { Cytb for Lates calcarifer and } \\
\text { Lates niloticus ( Schiefenhövel } \\
\text { \& Rehbein, 2011), } \\
\text { COI (Ivanova et al, 2007) } \\
\text { 16S-rRNA (Pardo et al, 2005) }\end{array}$ \\
\hline Germany & L 11.00-7 & universal & Cytb \\
\hline Germany & L 11.00-7, L 11.00-12 & universal/specific & $\begin{array}{l}\text { first cholce: Cytb, } \\
\text { nuclear parvalbumin, } \\
\text { CytcOI, 16SrRNA, } \\
\text { nuclear Calmodulin and } \\
\text { Rhodopsin }\end{array}$ \\
\hline Germany & $\begin{array}{l}\text { only DNA- sequencing } \\
\text { methods }\end{array}$ & $\begin{array}{l}\text { generelly universal, } \\
\text { sometimes specific }\end{array}$ & mitochondrial and nuclear DNA \\
\hline Germany & L 11.00-7, L 11.00-12 & universal & mitochondrial DNA \\
\hline Germany & L 11.00-6, L 11.00-12 & universal & Cytb \\
\hline \multirow[t]{2}{*}{ Germany } & L 11.00-7, L 11.00-12 & universal & Cytb \\
\hline & L 11.00-6, L 10.00-12 & $\begin{array}{l}\text { generelly universal, } \\
\text { sometimes specific }\end{array}$ & $\begin{array}{l}\text { mitochondrial DNA : Cytb, } \\
\text { CytOx, sometimes ATPase, } \\
\text { NADH dehydrogenase or } 16 S \\
\text { rRNA }\end{array}$ \\
\hline Germany & $\begin{array}{l}\text { mostly Real Time PCR } \\
\text { (Inhouse methods), than } \\
\text { PCR+ } \\
\text { sequencing }\end{array}$ & $\begin{array}{l}\text { specific Inhouse Real } \\
\text { Time PCR methods }\end{array}$ & mitochondrial Gens \\
\hline Germany & PCR + Sequencing & universal & Cytb \\
\hline
\end{tabular}




\begin{tabular}{|c|c|c|c|}
\hline & AUCuI & TDIVIAIVUCRII & \\
\hline Species & databases & developing methods & Public or private insti \\
\hline White fish & own & no & public \\
\hline $\begin{array}{l}\text { Gadoids, Salmonids, } \\
\text { Pleuronectiformes, Tunas, } \\
\text { Pangasius, Prawns }\end{array}$ & own, public & yes, novel agilent protocols & private \\
\hline Salmoinds, White fish & own & no & public \\
\hline White fish & own & no & public \\
\hline $\begin{array}{l}\text { Tuna, White fish, Hake, } \\
\text { Pleuronectiformes }\end{array}$ & own & & private \\
\hline White fish & own & FINS & public \\
\hline White fish & both & no & public \\
\hline $\begin{array}{l}\text { Salmonids, White fish, } \\
\text { Pleuronectiformes }\end{array}$ & own & no & public \\
\hline White fish, salmonids, praen & own & no & private \\
\hline Cod haddock & both & no & public \\
\hline Tunas, Anchovies, gadoids & own, public & $\begin{array}{l}\text { RT-PCR (TaqMan probes), PCR- } \\
\text { ELISA }\end{array}$ & public \\
\hline Tunas, Anchovies & own, public & TaqMan probes & private \\
\hline & public & no & public \\
\hline Bivalve molluscs & public & SSRs & public \\
\hline $\begin{array}{l}\text { Tunas, anchovies, bivalve } \\
\text { molluscs }\end{array}$ & own, public & Real Time-PCR & public \\
\hline $\begin{array}{l}\text { hake, cod, tunas, anchovies and } \\
\text { molluscs }\end{array}$ & own & Real Time-PCR & private \\
\hline hake, sardine & public & no & private \\
\hline hake, sardine, tuna & own & no & public \\
\hline Tuna, cephalopods, mussels & own & Real Time-PCR & private \\
\hline Mussels & public & RFLP & private \\
\hline tunas & public & no & public \\
\hline Theragra chalcogramma, cod, Ga & own, public & DHPLC & private \\
\hline freshwater fish & own & & private \\
\hline Gadus morhua, thunnus, lophius & own & no & public \\
\hline cod, hoki, tuna, tropical soles, Ala & own & & private \\
\hline p species & clients's databases & no & private \\
\hline salmonids & own & no & university \\
\hline Fish, Crustacean, Mollusc & own, public & yes & private \\
\hline $\begin{array}{l}\text { Sole } \\
\text { butterfish } \\
\text { salmonids }\end{array}$ & Fisch-DB & no & public \\
\hline no special fish & $\begin{array}{l}\text { own databases, } \\
\text { EMBL/NCBI }\end{array}$ & no & private \\
\hline $\begin{array}{l}\text { a huge diversity of fish } \\
\text { with main focus on sole }\end{array}$ & BLAST/NCBI & no & public \\
\hline
\end{tabular}




\begin{tabular}{|c|c|c|c|}
\hline Acipenser species (Caviar) & Acuet & 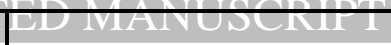 & \\
\hline $\begin{array}{l}\text { Cod } \\
\text { zander } \\
\text { European perch }\end{array}$ & BLAST/NCBI & not in terms of fish & public \\
\hline sole & $\begin{array}{l}\text { BLAST/NCBI, own } \\
\text { reference samples } \\
\text { /sequences }\end{array}$ & no & public \\
\hline plaice, turbot, flounder, sole & $\begin{array}{l}\text { own reference } \\
\text { sample }\end{array}$ & no & public \\
\hline no special fish & NCBI & no & public \\
\hline $\begin{array}{l}\text { mostly: plaice, sole and halibut; } \\
\text { regularly: gilthead seabream, } \\
\text { saithe, cod, salmonids, } \\
\text { pangasius } \\
\text { in generell the hole range of fish } \\
\text { species in the German market }\end{array}$ & $\begin{array}{l}\text { BLAST/NCBI, own } \\
\text { reference samples } \\
\text { /sequences }\end{array}$ & no & public \\
\hline $\begin{array}{l}\text { saithe, Alaska pollack, cod, } \\
\text { tilapia, pangasius, salmonids, } \\
\text { sole, flounder, plaice, hake, } \\
\text { redfish }\end{array}$ & $\begin{array}{l}\text { PCR-RFLP: } \$ 64 \\
\text { method, FischDB, } \\
\text { own reference } \\
\text { samples }\end{array}$ & no & public \\
\hline non specific & $\begin{array}{l}\text { NCBI, barcode of } \\
\text { live and Fish DB }\end{array}$ & no & public \\
\hline $\begin{array}{l}\text { the whole range of fishes, } \\
\text { nowadays tuna, scallops and } \\
\text { crustacea }\end{array}$ & $\begin{array}{l}\text { own databank and } \\
\mathrm{NCBI}\end{array}$ & yes & private \\
\hline salmonids and caviar & $\begin{array}{l}\text { reference samples, } \\
\S 64-\text { Method, } \\
\text { Fish-DB for PCR- } \\
\text { RFLP and NCBI for } \\
\text { sequencing }\end{array}$ & $\nabla$ & public \\
\hline $\begin{array}{l}\text { sole, plaice, other flatfishes } \\
\text { angler-fish, }\end{array}$ & $\begin{array}{l}\text { own databank for } \\
\text { IEF and } \\
\text { Blast /NCBI }\end{array}$ & no & public \\
\hline halibut, butterfish, tuna & NCBI & no & public \\
\hline $\begin{array}{l}\text { the whole range of fishes, main } \\
\text { focus on flatfish, scallops, } \\
\text { crustacean; nowadays snapper } \\
\text { and anglerfish }\end{array}$ & $\begin{array}{l}\text { NCBI, reference } \\
\text { samples }\end{array}$ & no & public \\
\hline $\begin{array}{l}\text { Alaska pollack, tuna, hering, } \\
\text { cod, pangasius, redfish, sardine, } \\
\text { plaice, sole, turbot, halibut, } \\
\text { tilapia }\end{array}$ & $\begin{array}{l}\text { own databank for } \\
\text { Real time PCR, } \\
\text { BLAST/NCBI }\end{array}$ & $\begin{array}{l}\text { yes: the species specific } \\
\text { Real Time PCR methods }\end{array}$ & private \\
\hline flatfish, other species & NCBI and Fishbase & yes & public \\
\hline
\end{tabular}




\section{tution}

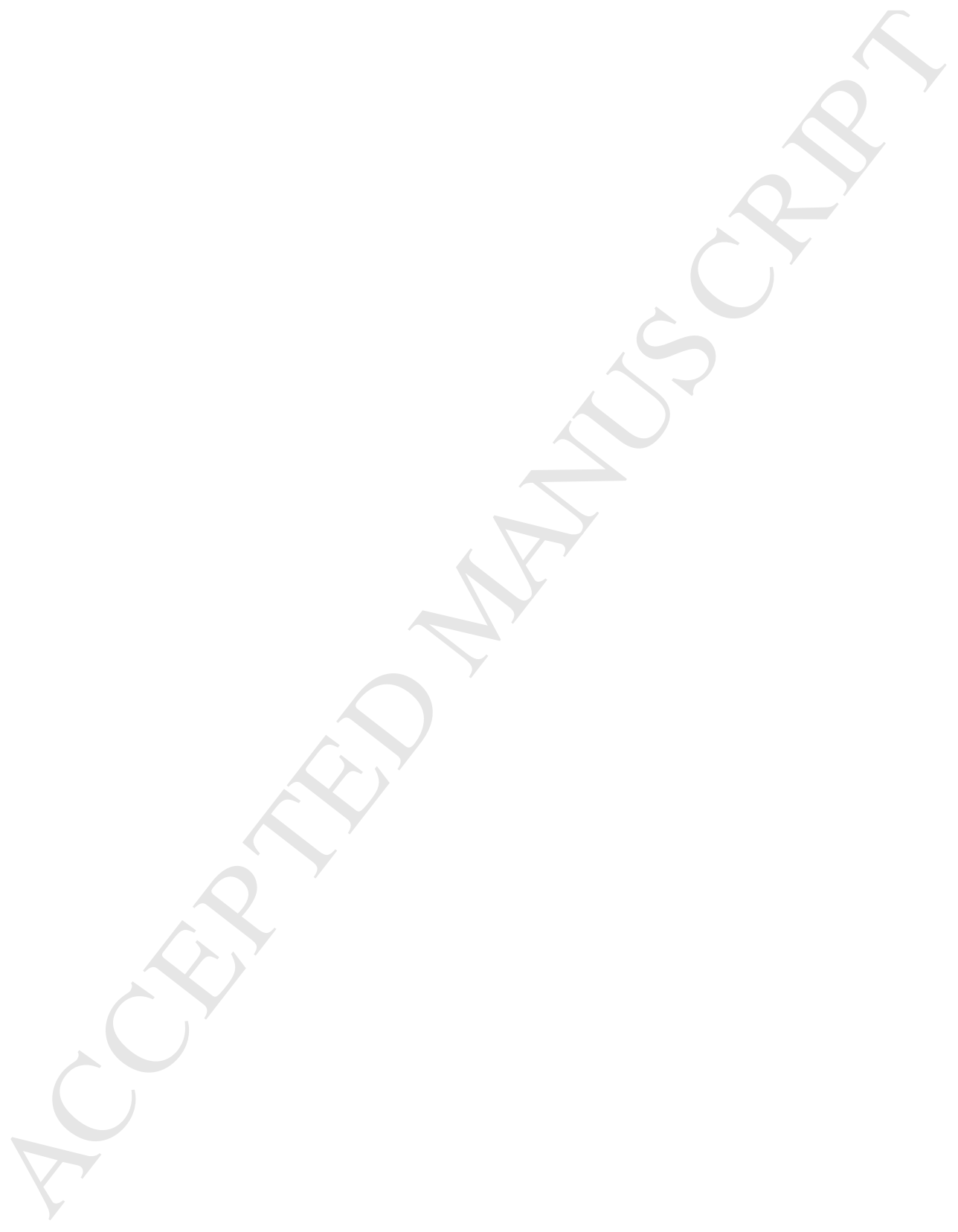




\begin{tabular}{|c|c|c|c|c|}
\hline & 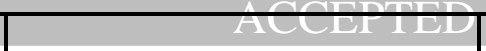 & IVARUSCOAPI & Gadoids/P & \\
\hline Country & Species & Species Class & angasius & Salmonids \\
\hline UK & White fish & Gadoids/Pangasius & 1 & 0 \\
\hline UK & $\begin{array}{l}\text { Gadoids, Salmonids, } \\
\text { Pleuronectiformes, Tunas, } \\
\text { Pangasius, Prawns }\end{array}$ & $\begin{array}{l}\text { Gadoids/Pangasius, Salmonids, } \\
\text { Pleuronectiformes, Tunas, } \\
\text { Invertebrates }\end{array}$ & 1 & 1 \\
\hline UK & Salmoinds, White fish & Gadoids/Pangasius, Salmonids & 1 & 1 \\
\hline UK & White fish & Gadoids/Pangasius & 1 & 0 \\
\hline UK & $\begin{array}{l}\text { Tuna, White fish, Hake, } \\
\text { Pleuronectiformes }\end{array}$ & $\begin{array}{l}\text { Gadoids/Pangasius, Hakes, } \\
\text { Pleuronectiformes, Tunas }\end{array}$ & 1 & 0 \\
\hline UK & White fish & Gadoids/Pangasius & 1 & 0 \\
\hline UK & White fish & Gadoids/Pangasius & 1 & 0 \\
\hline IIIK & Salmonids, White fish, & Gadoids/Pangasius, Salmonids, & 1 & 1 \\
\hline . & & Gadoids/Pangasius, salmonids, & & $\perp$ \\
\hline UK & White fish, salmonids, prawn & Invertebrates & 1 & 1 \\
\hline UK & Cod haddock & Gadoids/Pangasius & 1 & 0 \\
\hline Spain & Tunas, Anchovies, gadoids & $\begin{array}{l}\text { Tunas, Clupeids, } \\
\text { Gadoids/Pangasius }\end{array}$ & 1 & 0 \\
\hline Spain & Tunas, Anchovies & Tunas, Clupeids & 0 & 0 \\
\hline Spain & Bivalve molluscs & Invertebrates & 0 & 0 \\
\hline Spain & $\begin{array}{l}\text { Tunas, anchovies, bivalve } \\
\text { molluscs }\end{array}$ & Tunas, Invertebrates, Clupeids & 0 & 0 \\
\hline Spain & $\begin{array}{l}\text { hake, cod, tunas, anchovies and } \\
\text { molluscs }\end{array}$ & $\begin{array}{l}\text { Hakes, Tunas, Clupeids, } \\
\text { Gadoids/Pangasius, } \\
\text { Invertebrates }\end{array}$ & 1 & 0 \\
\hline Spain & hake, sardine & Hakes, Tunas & 0 & 0 \\
\hline Spain & hake, sardine, tuna & Hakes, Clupeids, Tunas & 0 & 0 \\
\hline Spain & Tuna, cephalopods, mussels & Tunas, Invertebrates & 0 & 0 \\
\hline Spain & Mussels & Invertebrates & 0 & 0 \\
\hline Spain & tunas & Tunas & 0 & 0 \\
\hline France & \multirow{4}{*}{\multicolumn{2}{|c|}{$\begin{array}{l}\text { Theragra chalcogramma, cod, Gaı Gadoids/Pangasius, Salmonids, TI } \\
\text { Gadus morhua, thunnus, lophius Gadoids/Pangasius, Lophius, Tuni } \\
\text { cod, hoki, tuna, tropical soles, Ala Tuna, Gadoids/Pangasius, Pleurol }\end{array}$}} & 1 & 1 \\
\hline France & & & 1 & 0 \\
\hline France & & & 1 & 1 \\
\hline ROI & & & 0 & 1 \\
\hline Germany & $\begin{array}{l}\text { sole } \\
\text { butterfish } \\
\text { salmonids }\end{array}$ & $\begin{array}{l}\text { Salmonids, Pleuronectiformes, } \\
\text { Butterfish }\end{array}$ & 0 & 1 \\
\hline Germany & $\begin{array}{l}\text { a huge diversity of fish } \\
\text { with main focus on sole }\end{array}$ & Pleuronectiformes & 0 & 0 \\
\hline & $\begin{array}{l}\text { Acipenser species (Caviar) } \\
\text { Cod } \\
\text { zander }\end{array}$ & Caviar, Gadoids/Pangasius, & & \\
\hline Germany & European perch & Zander, Perch & 1 & 0 \\
\hline Germany & sole & Pleuronectiformes & 0 & 0 \\
\hline Germany & plaice, turbot, flounder, sole & Pleuronectiformes & 0 & 0 \\
\hline Germany & $\begin{array}{l}\text { mostly: plaice, sole and halibut; } \\
\text { regularly: gilthead seabream, } \\
\text { saithe, cod, salmonids, } \\
\text { pangasius } \\
\text { in generell the hole range of fish } \\
\text { species in the German market }\end{array}$ & $\begin{array}{l}\text { Pleuronectiformes, } \\
\text { Gadoids/Pangasius, salmonids, } \\
\text { Seabream }\end{array}$ & 1 & 1 \\
\hline
\end{tabular}




\begin{tabular}{|c|c|c|c|c|}
\hline & saithe, Alaska pollack, cod, 1 - & IVARUSGATI & & \multirow{3}{*}{1} \\
\hline Germany & $\begin{array}{l}\text { tilapia, pangasius, salmonids, } \\
\text { sole, flounder, plaice, hake, } \\
\text { redfish }\end{array}$ & $\begin{array}{l}\text { Pleuronectiformes, } \\
\text { Gadoids/Pangasius, Salmonids, } \\
\text { Hakes, Redfish/Snapper }\end{array}$ & \multirow[t]{2}{*}{1} & \\
\hline Germany & $\begin{array}{l}\text { the whole range of fishes, } \\
\text { nowadays tuna, scallops and } \\
\text { crustacea }\end{array}$ & Tunas, Invertebrates & & \\
\hline Germany & salmonids and caviar & Salmonids, Caviar & 0 & 1 \\
\hline Germany & $\begin{array}{l}\text { sole, plaice,other flatfishes } \\
\text { angler-fish, }\end{array}$ & Pleuronectiformes, Lophius & 0 & 0 \\
\hline Germany & halibut, butterfish, tuna & $\begin{array}{l}\text { Pleuronectiformes, Tunas, } \\
\text { Butterfish }\end{array}$ & & 0 \\
\hline Germany & $\begin{array}{l}\text { the whole range of fishes, main } \\
\text { focus on flatfish, scallops, } \\
\text { crustacean; nowadays snapper } \\
\text { and anglerfish }\end{array}$ & $\begin{array}{l}\text { Pleuronectiformes, Lophius, } \\
\text { Redfish/Snapper, Invertebrates }\end{array}$ & 0 & 0 \\
\hline Germany & $\begin{array}{l}\text { Alaska pollack, tuna, hering, } \\
\text { cod, pangasius, redfish, sardine, } \\
\text { plaice, sole, turbot, halibut, } \\
\text { tilapia }\end{array}$ & Tuna, Gadoids/Pangasius, Clupeic & 1 & 0 \\
\hline Germany & flatfish, other species & Pleuronectiformes & 0 & 0 \\
\hline & & 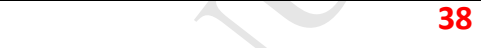 & 19 & 11 \\
\hline
\end{tabular}




\begin{tabular}{|c|c|c|c|c|c|c|c|c|c|}
\hline & 1 & & $\mathrm{AC}$ & EPTED I & IANUS & RI & & & \\
\hline Flat Fish & |Tunas & Hakes & Inverts & Clupeids & Caviar & & h Zander & & \\
\hline & 0 & 0 & 0 & 0 & 0 & 0 & 0 & 0 & 0 \\
\hline & 1 & 1 & 0 & 1 & 0 & 0 & 0 & 0 & 0 \\
\hline & 0 & 0 & 0 & 0 & 0 & 0 & 0 & 0 & 0 \\
\hline & 0 & 0 & 0 & 0 & 0 & 0 & 0 & 0 & 0 \\
\hline & 1 & 1 & 1 & 0 & 0 & 0 & 0 & 0 & 0 \\
\hline & 0 & 0 & 0 & 0 & 0 & 0 & 0 & 0 & 0 \\
\hline & 0 & 0 & 0 & 0 & 0 & 0 & 0 & 0 & 0 \\
\hline & 1 & 0 & 0 & 0 & 0 & 0 & 0 & 0 & 0 \\
\hline & 0 & 0 & 0 & 1 & 0 & 0 & 0 & 0 & 0 \\
\hline & 0 & 0 & 0 & 0 & 0 & 0 & 0 & 0 & 0 \\
\hline & 0 & 1 & 0 & 0 & 1 & 0 & 0 & 0 & 0 \\
\hline & 0 & 1 & 0 & 0 & 1 & 0 & 0 & 0 & 0 \\
\hline & 0 & 0 & 0 & 1 & 0 & 0 & 0 & 0 & 0 \\
\hline & 0 & 1 & 0 & 1 & 1 & 0 & 0 & 0 & 0 \\
\hline & 0 & 1 & 1 & 1 & 0 & 0 & 0 & 0 & 0 \\
\hline & 0 & 1 & 1 & 0 & 0 & 0 & 0 & 0 & 0 \\
\hline & 0 & 1 & 1 & 0 & 0 & 0 & 0 & 0 & 0 \\
\hline & 0 & 1 & 0 & 1 & 0 & 0 & 0 & 0 & 0 \\
\hline & 0 & 0 & 0 & 1 & 0 & 0 & 0 & 0 & 0 \\
\hline & 0 & 1 & 0 & 0 & 0 & 0 & 0 & 0 & 0 \\
\hline & 0 & 1 & 0 & 0 & 0 & 0 & 0 & 0 & 0 \\
\hline & 0 & 1 & 0 & 0 & 0 & 0 & 0 & 0 & 0 \\
\hline & 1 & 1 & 0 & 0 & 0 & 0 & 0 & 0 & 0 \\
\hline & 0 & 0 & 0 & 0 & 0 & 0 & 0 & 0 & 0 \\
\hline & 1 & 0 & & 0 & 0 & 0 & 1 & 0 & 0 \\
\hline & 1 & 0 & 0 & 0 & 0 & 0 & 0 & 0 & \\
\hline
\end{tabular}

$\begin{array}{lllllllll}0 & 0 & 0 & 0 & 0 & 1 & 0 & 1 & 1 \\ 1 & 0 & 0 & 0 & 0 & 0 & 0 & 0 & 0 \\ 1 & 0 & 0 & 0 & 0 & 0 & 0 & 0 & 0\end{array}$




\begin{tabular}{|c|c|c|c|c|c|c|c|c|}
\hline 1 & 0 & 1 & 0 & 0 & 0 & 0 & 0 & 0 \\
\hline 0 & 1 & 0 & 1 & 0 & 0 & 0 & 0 & 0 \\
\hline 0 & 0 & 0 & 0 & 0 & 1 & 0 & 0 & 0 \\
\hline 1 & 0 & 0 & 0 & 0 & 0 & 0 & 0 & 0 \\
\hline 1 & 1 & 0 & 0 & 0 & 0 & 1 & & 0 \\
\hline 1 & 0 & 0 & 1 & 0 & 0 & & 0 & 0 \\
\hline 1 & 0 & 0 & 0 & 1 & 0 & 0 & 0 & 0 \\
\hline 1 & 0 & 0 & 0 & 0 & 0 & 0 & 0 & 0 \\
\hline 15 & 15 & 5 & 9 & 4 & & 2 & 1 & 1 \\
\hline
\end{tabular}


ACCEPTED MANUSCRIPT

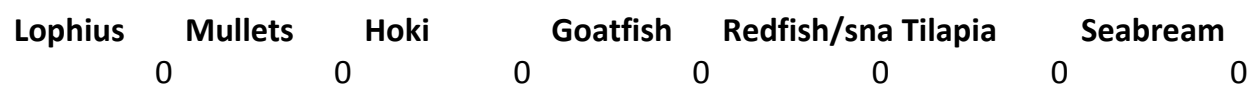

$\begin{array}{lllllll}0 & 0 & 0 & 0 & 0 & 0 & 0 \\ 0 & 0 & 0 & 0 & 0 & 0 & 0 \\ 0 & 0 & 0 & 0 & 0 & 0 & 0 \\ 0 & 0 & 0 & 0 & 0 & 0 & 0 \\ 0 & 0 & 0 & 0 & 0 & 0 & 0 \\ 0 & 0 & 0 & 0 & 0 & 0 & 0 \\ & & & & & & \\ 0 & 0 & 0 & 0 & 0 & 0 & 0 \\ 0 & 0 & 0 & 0 & 0 & 0 & 0 \\ 0 & 0 & 0 & 0 & 0 & 0 & 0 \\ 0 & 0 & 0 & 0 & 0 & 0 & 0 \\ 0 & 0 & 0 & 0 & 0 & 0 & 0 \\ 0 & 0 & 0 & 0 & 0 & 0 & 0 \\ 0 & 0 & 0 & 0 & 0 & 0 & 0\end{array}$

$\begin{array}{lllllll}0 & 0 & 0 & 0 & 0 & 0 & 0 \\ 0 & 0 & 0 & 0 & 0 & 0 & 0 \\ 0 & 0 & 0 & 0 & 0 & 0 & 0 \\ 0 & 0 & 0 & 0 & 0 & 0 & 0 \\ 0 & 0 & 0 & 0 & 0 & 0 & 0 \\ 0 & 0 & 0 & 0 & 0 & 0 & 0 \\ 0 & 0 & 0 & 0 & 0 & 0 & 0 \\ 1 & 0 & 0 & 0 & 0 & 0 & 0 \\ 1 & 1 & 1 & 1 & 0 & 0 & 0 \\ 0 & 0 & 0 & 0 & 0 & 0 & 0\end{array}$

$\begin{array}{lllllll}0 & 0 & 0 & 0 & 0 & 0 & 0 \\ 0 & 0 & 0 & 0 & 0 & 0 & 0\end{array}$

$\begin{array}{lllllll}0 & 0 & 0 & 0 & 0 & 0 & 0 \\ 0 & 0 & 0 & 0 & 0 & 0 & 0 \\ 0 & 0 & 0 & 0 & 0 & 0 & 0\end{array}$

0

0

0

0

0

0 


$\begin{array}{lllllll}0 & 0 & 0 & 0 & 1 & 0 & 0 \\ 0 & 0 & 0 & 0 & 0 & 0 & 0 \\ 0 & 0 & 0 & 0 & 0 & 0 & 0 \\ 1 & 0 & 0 & 0 & 0 & 0 & 0 \\ 0 & 0 & 0 & 0 & 0 & 0 & 0\end{array}$

0

0

1

0

0

0
0
3

0
0
1

0
0
1

0
0
1

1
0
3

$\begin{array}{ll}1 & 0 \\ 0 & 0 \\ 1 & 1\end{array}$

$\square$ 
।

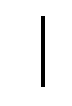

। 
Supplementary Material 4. PCA the species commonly tested in each authenticity laboratory, including all classifications of products (including the nine classes with only one or two responses that were removed from fig 1). PC 1 incorporates $21.6 \%$ and PC $216.4 \%$ of the variation (eigenvalues $=0.388$ and 0.294 , respectively).

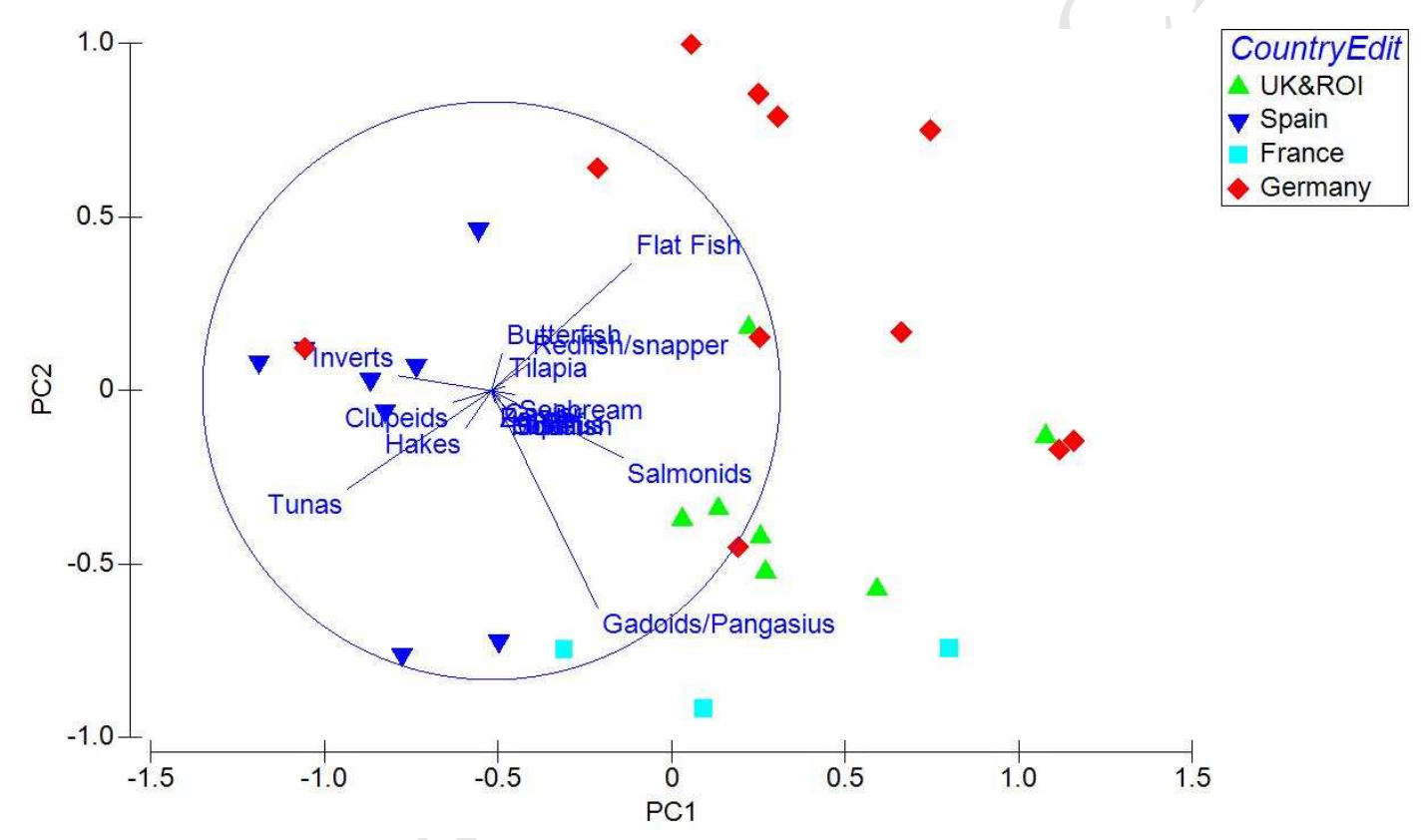




\begin{tabular}{|c|c|c|c|c|c|c|}
\hline Country & Method classifed & FINS & \begin{tabular}{|l|l|l|} 
RFLP & IEF \\
\end{tabular} & rtPCR & & \\
\hline UK & IEF, RFLP & 0 & 1 & 1 & 0 & 0 \\
\hline UK & FINS, RFLP & 1 & 1 & 0 & 0 & 0 \\
\hline UK & RFLP & 0 & 1 & 0 & 0 & 0 \\
\hline UK & RFLP & 0 & 1 & 0 & 0 & 0 \\
\hline UK & RFLP & 0 & 1 & 0 & 0 & 0 \\
\hline UK & FINS, RFLP & 1 & 1 & 0 & 0 & 0 \\
\hline UK & RFLP & 0 & 1 & 0 & 0 & 0 \\
\hline UK & IEF, RFLP & 0 & 1 & 1 & 0 & 0 \\
\hline UK & IEF & 0 & 0 & 1 & 0 & 0 \\
\hline UK & RFLP & 0 & 1 & 0 & 0 & 0 \\
\hline Spain & FINS & 1 & 0 & 0 & 0 & 0 \\
\hline Spain & FINS, rtPCR & 1 & 0 & 0 & 1 & 0 \\
\hline Spain & FINS,SDS-PAGE, IEF, RAPD & 1 & 0 & 1 & 0 & 0 \\
\hline Spain & FINS & 1 & 0 & 0 & 0 & 0 \\
\hline Spain & FINS & 1 & 0 & 0 & 0 & 0 \\
\hline Spain & FINS, Ssprimers & 1 & 0 & 0 & 0 & 1 \\
\hline Spain & RFLP, rtPCR & 0 & 1 & 0 & 1 & 0 \\
\hline Spain & SNPS, FINS, ELISA & 1 & 0 & 0 & 0 & 0 \\
\hline Spain & FINS, RFLP & 1 & 1 & 0 & 0 & 0 \\
\hline Spain & FINS, RFLP & 1 & 1 & 0 & 0 & 0 \\
\hline Spain & Ssprimers & 0 & 0 & 0 & 0 & 1 \\
\hline France & SSprimers, FINS, DHPLC & 1 & 0 & 0 & 0 & 1 \\
\hline France & FINS, NGS & 1 & 0 & 0 & 0 & 0 \\
\hline France & IEF, RFLP & 0 & 1 & 1 & 0 & 0 \\
\hline France & IEF & 0 & 0 & 1 & 0 & 0 \\
\hline France & RT-PCR, FINS & 1 & 0 & 0 & 1 & 0 \\
\hline $\mathrm{ROI}$ & FINS, MSAT & 1 & 0 & 0 & 0 & 0 \\
\hline Portugal & FINS & 1 & 0 & 0 & 0 & 0 \\
\hline Germany & FINS, RFLP & 1 & 1 & 0 & 0 & 0 \\
\hline Germany & FINS, RFLP, rtPCR & 1 & 1 & 0 & 1 & 0 \\
\hline Germany & $\infty y$ & 1 & 0 & 0 & 0 & 0 \\
\hline Germany & 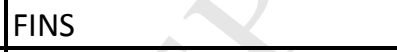 & 1 & 0 & 0 & 0 & 0 \\
\hline Germany & FINS & 1 & 0 & 0 & 0 & 0 \\
\hline Germany & IEF & 0 & 0 & 1 & 0 & 0 \\
\hline Germany & FINS & 1 & 0 & 0 & 0 & 0 \\
\hline Germany & FINS & 1 & 0 & 0 & 0 & 0 \\
\hline Germany & RFLP & 0 & 1 & 0 & 0 & 0 \\
\hline Germany & FINS, RFLP & 1 & 1 & 0 & 0 & 0 \\
\hline Germany & FINS & 1 & 0 & 0 & 0 & 0 \\
\hline Germany & FINS, RFLP & 1 & 1 & 0 & 0 & 0 \\
\hline Germany & IEF, FINS & 1 & 1 & 0 & 0 & 0 \\
\hline Germany & IEF, FINS & 1 & 0 & 1 & 0 & 0 \\
\hline Germany & IEF, FINS & 1 & 0 & 1 & 0 & 0 \\
\hline Germany & rtPCR, FINS & 1 & 0 & 0 & 1 & 0 \\
\hline Germany & FINS & 1 & 0 & 0 & 0 & 0 \\
\hline \multicolumn{2}{|l|}{ TOTAL } & 31 & 19 & 9 & 5 & 3 \\
\hline
\end{tabular}




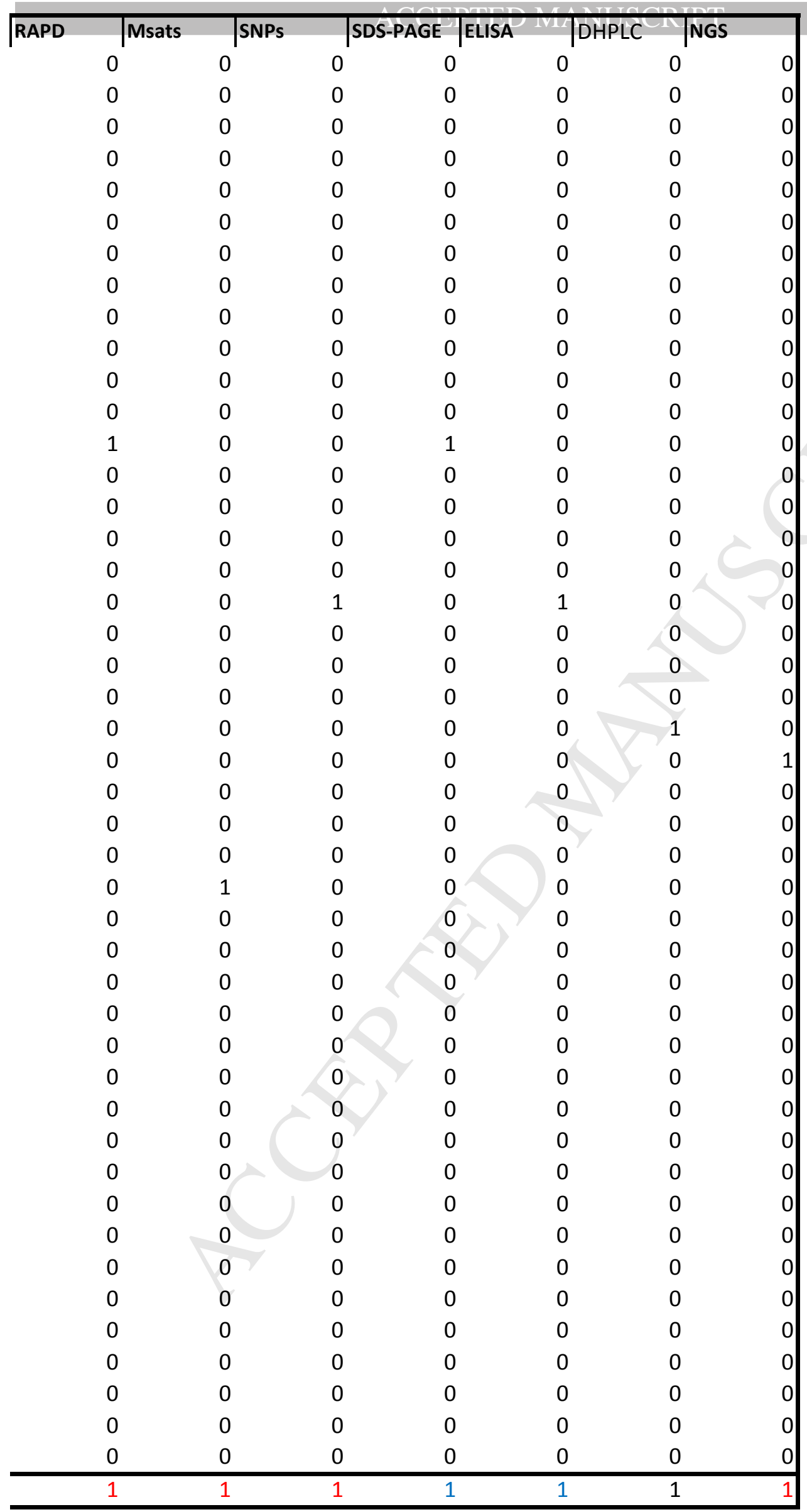




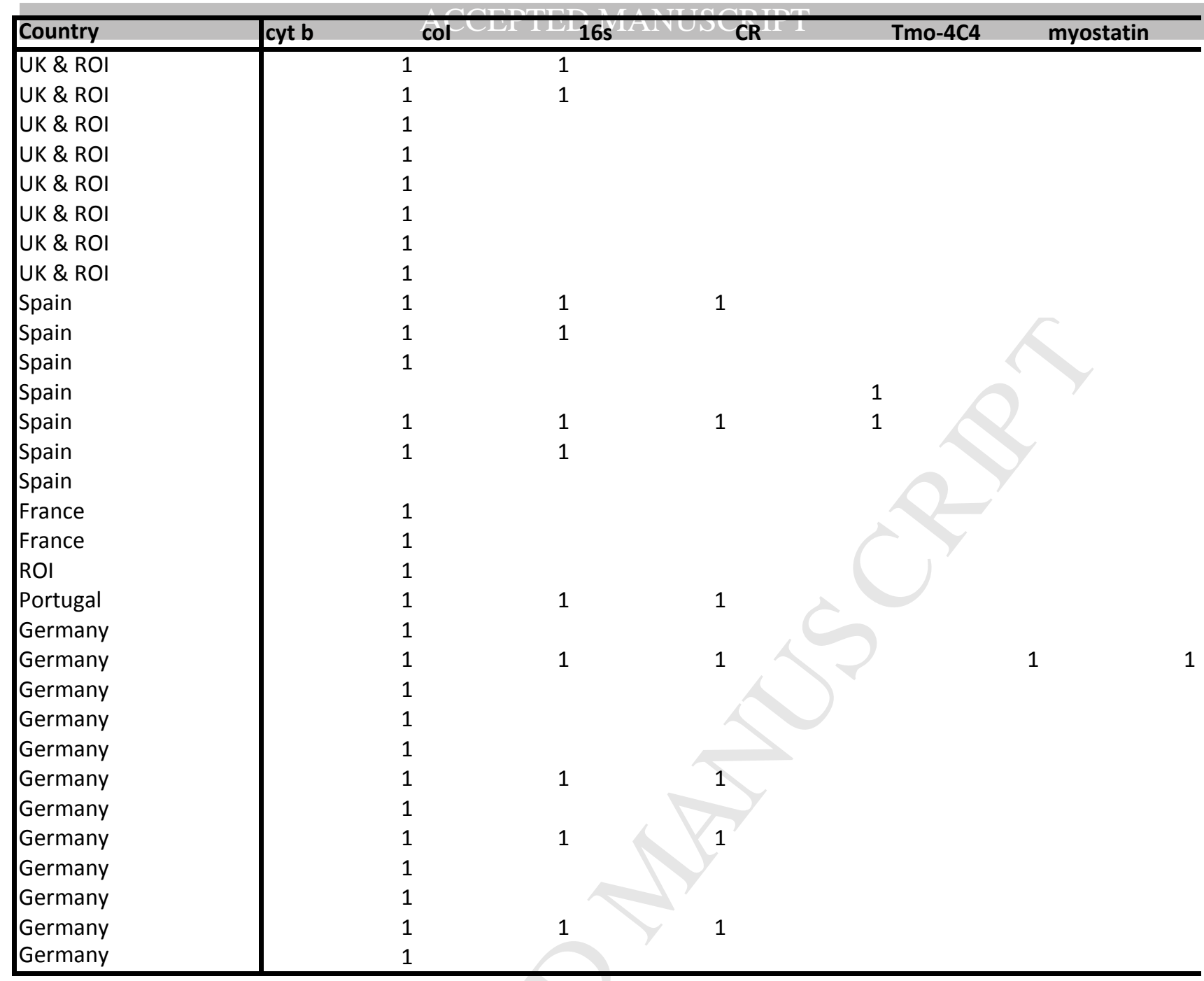




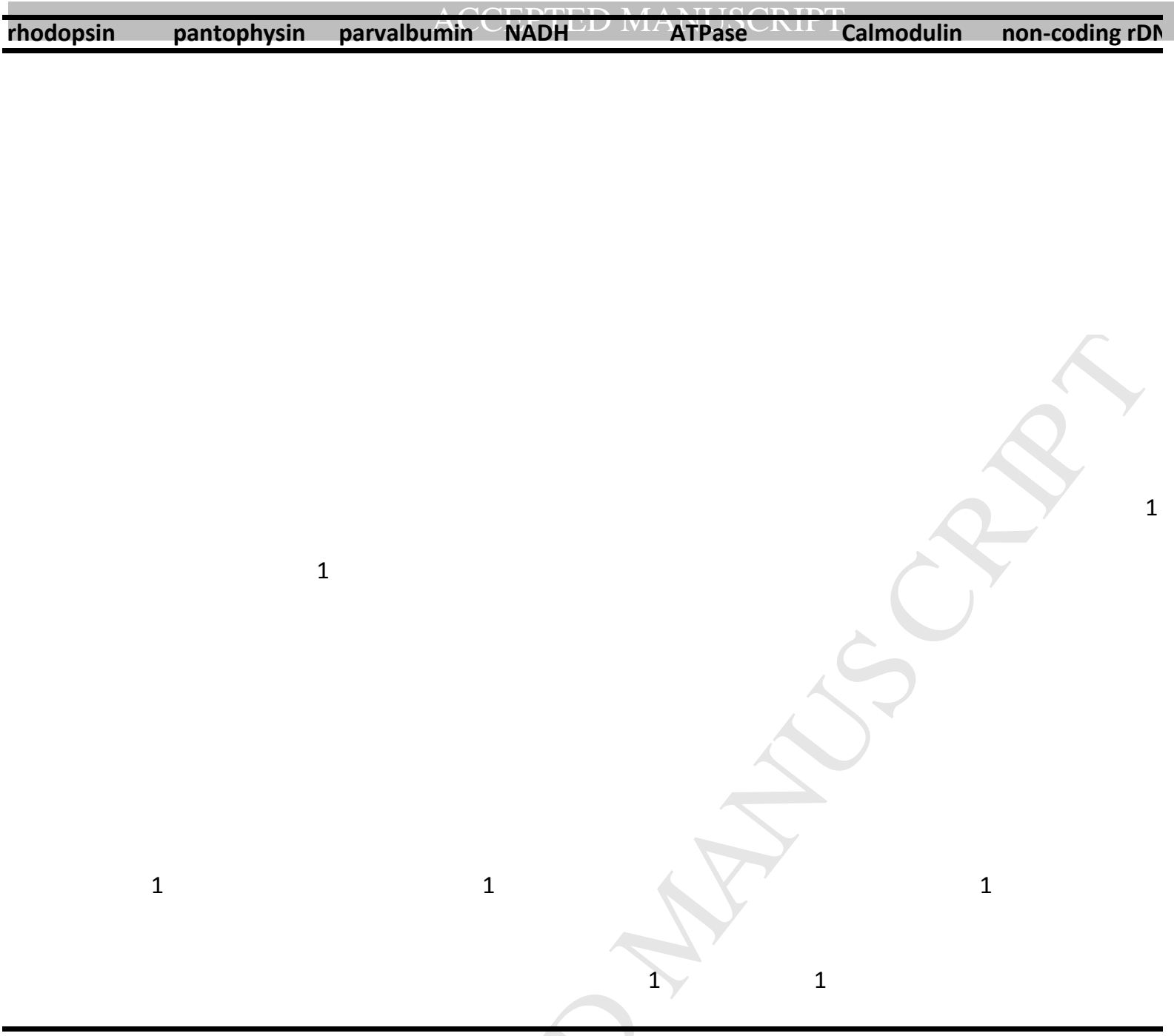


Supplementary Material 6. PCA the methods utilised in each authenticity laboratory including all classifications of methods (including those with a single record were that were removed from fig 2). PC 1 incorporates 35.8\% and PC $232.3 \%$ of the variation (eigenvalues $=0.341$ and 0.221 , respectively). Methodological abbreviations; FINS = forensically informative nucleotide sequencing, RFLP $=$ restriction fragment length polymorphism, IEF isoelectric focusing, $r$ tPCR $=$ real-time polymerase chain reaction \& SSprimers = species specific primers.
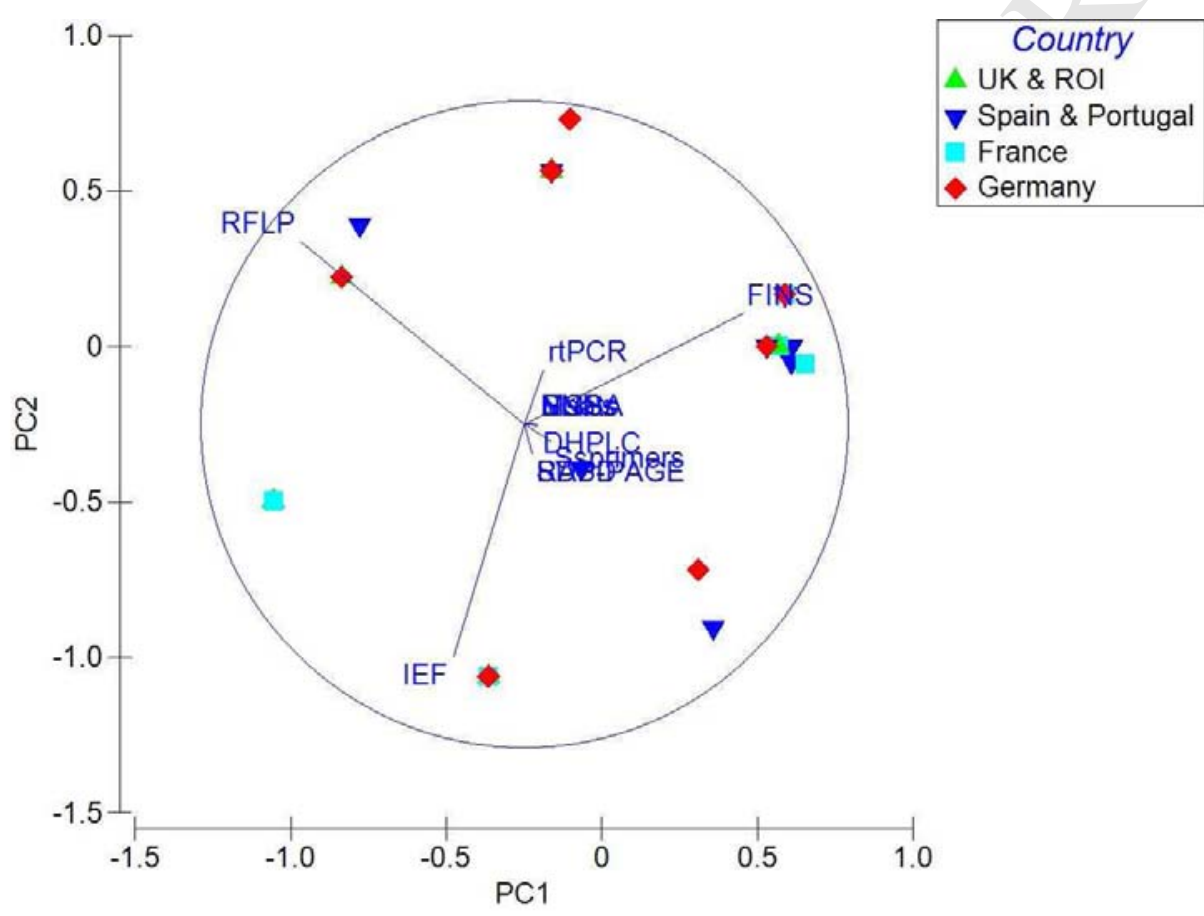